\title{
Archaeological Investigation of a Spring Lake Lot for Joe's Crab Shack Parking
}

Owen A. Ford

Center for Archaeological Research

Anthony S. Lyle

Center for Archaeological Research

Follow this and additional works at: https://scholarworks.sfasu.edu/ita

Part of the American Material Culture Commons, Archaeological Anthropology Commons, Environmental Studies Commons, Other American Studies Commons, Other Arts and Humanities Commons, Other History of Art, Architecture, and Archaeology Commons, and the United States History Commons

Tell us how this article helped you.

This Article is brought to you for free and open access by the Center for Regional Heritage Research at SFA ScholarWorks. It has been accepted for inclusion in Index of Texas Archaeology: Open Access Gray Literature from the Lone Star State by an authorized editor of SFA ScholarWorks. For more information, please contact cdsscholarworks@sfasu.edu. 


\section{Archaeological Investigation of a Spring Lake Lot for Joe's Crab Shack Parking \\ Creative Commons License \\ (c) (i) ()}

This work is licensed under a Creative Commons Attribution-NonCommercial 4.0 International License 
Center for Archaeological Research * The University of Texas at San Antonio Archaeological Survey Report, No. $277 \div 1998$

\section{Archaeological Investigation of a Spring Lake Lot for Joe's Crab Shack Parking}

\section{Owen A. Ford and Anthony S. Lyle}

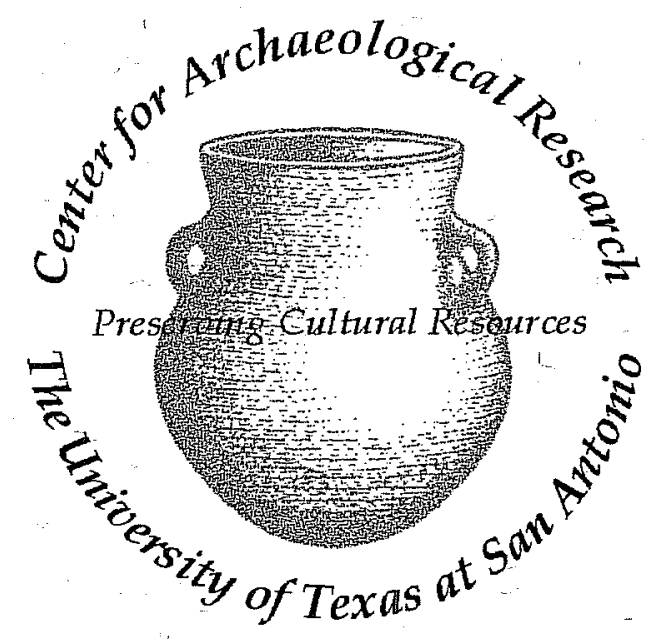





\section{Archaeological Investigation of a Spring Lake Lot for Joe's Crab Shack Parking}

Owen A. Ford and Anthony S. Lyle

Robert J. Hard and C. Britt Bousman

Prinicipal Investigator

Texas Antiquities Permit No. 1877

Ccopyright 1998

Archaeological Survey Report, No. 277

Center for Archaeological Research

The University of Texas at San Antonio 
The following information is provided in accordance with the General Rules of Practice and Procedure, Chapter 41.11 (Investigative Reports), Texas Antiquities Committee:

1. Type of investigation: Survey and testing

2. Project name: Spring Lake Lot

3. County: Hays

4. Principal investigator: Robert J. Hard and C. Britt Bousman

5. Name and location of sponsoring agency: Southwest Texas State University, San Marcos, Texas

6. Texas Antiquities Permit No.: 1877

7. Published by the Center for Archaeological Research, The University of Texas at San Antonio, 6900 N. Loop 1604 W., San Antonio, Texas 78249-0658, 1998

A list of publications offered by the Center for Archaeological Research is available. Call (210) 458-4378; write to the Center for Archaeological Research, The University of Texas at San Antonio, 6900 N. Loop 1604 W., San Antonio, Texas 78249-0658; e-mail to car@lonestar.utsa.edu; or visit CAR's web site at http://www.csbs.utsa.edu/research/car/index.htm. 


\begin{abstract}
On August 19 and 25, 1997, the Center for Archaeological Research (CAR) of The University of Texas at San Antonio conducted an intensive survey for cultural resources at the proposed location of a parking lot for Joe's Crab Shack Restaurants along Spring Lake, Hays County, Texas. The work was contracted by Southwest Texas State University (SWTSU) and conducted under Texas Antiquities Permit number 1877. Upon completion of the survey and subsurface testing, CAR determined that no cultural resources would be impacted by the planned parking lot construction. CAR therefore recommended that the project sponsor be allowed to proceed as planned with the proposed project and the Texas Historical Commission (THC) has concurred.
\end{abstract}




\section{Contents}

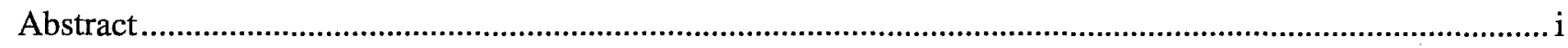

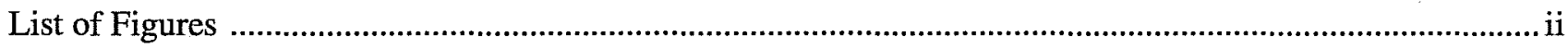

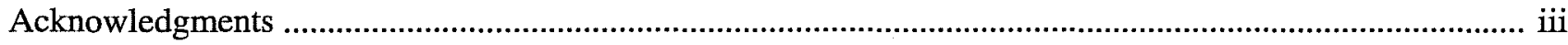

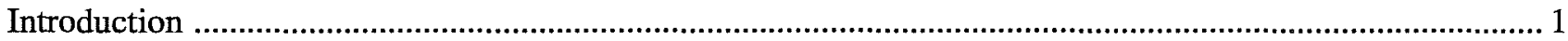

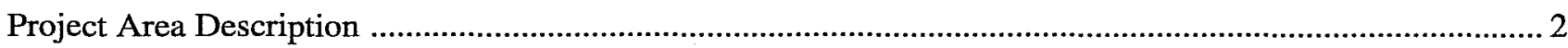

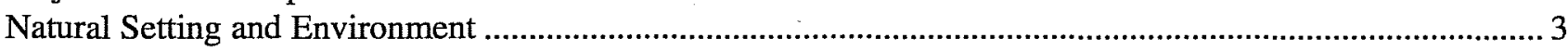

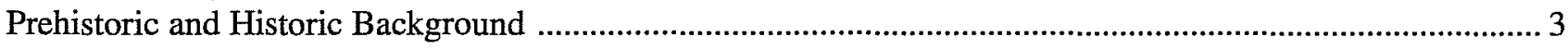

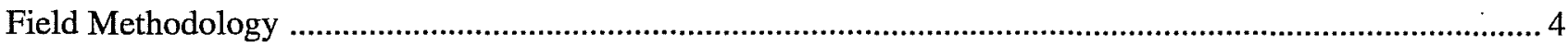

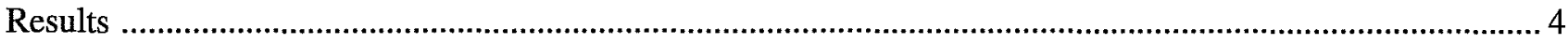

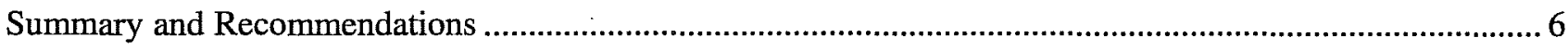

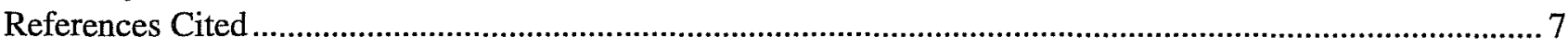

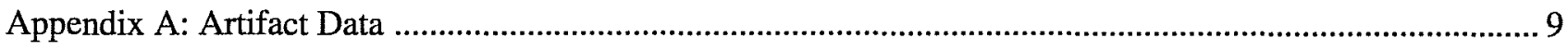

\section{Figures}

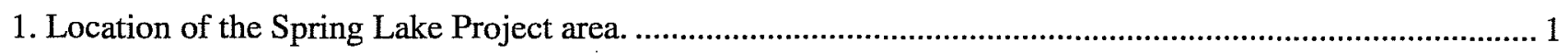

2. Location of archaeological sites around Spring Lake. ....................................................................... 2

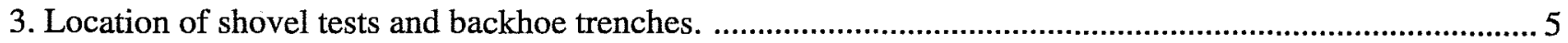




\section{Acknowledgments}

The authors would like to thank Shane Prochnow and Andrea Betzold for fieldwork and laboratory analysis. Further appreciation is due to Marcie Renner for editing assistance; to the principal and co-principal investigators Dr. Robert J. Hard and Dr. Britt Bousman, respectively, for their support and the opportunity to do this project; and to Chris Butler for his excellent drafting of the figures. Additional gratitude is extended to SWTSU Supervisor of Facilities Planning and Design Services Allen Henderson and to James Garber, Anthropology Department, SWTSU, as well as Chris Ringstaff for consultation on the geoarchaeology of Spring Lake and permission to use the map of sites in the area. 



\section{Introduction}

In August 1997, Southwest Texas State University (SWTSU) contracted the Center for Archaeological Research (CAR) of the University of Texas at San Antonio to identify and record cultural materials which might be affected by the construction for a parking lot installation along the southwest side of Spring Lake in Hays County, Texas (Figure 1). The property to be investigated is controlled by SWTSU, therefore, an archaeological survey is required by the Texas Antiquities Code. The close proximity of the previously identified and tested sites of $41 \mathrm{HY} 37$,
41HY147, 41HY160, 41HY161, and 41HY165 (Figure 2) reinforced the necessity of archaeological investigation in this area (Garber and Orloff 1984; Garber et al. 1983).

The fieldwork was conducted by Owen Ford and Anthony Lyle (project archaeologists), with Shane Prochnow and Andrea Betzold (field archaeologists) assisting. Principal investigator and co-principal investigator were Robert J. Hard and Britt Bousman, respectively. The project was conducted under Texas Antiquities Permit No. 1877 issued by the Texas Historical Commission.

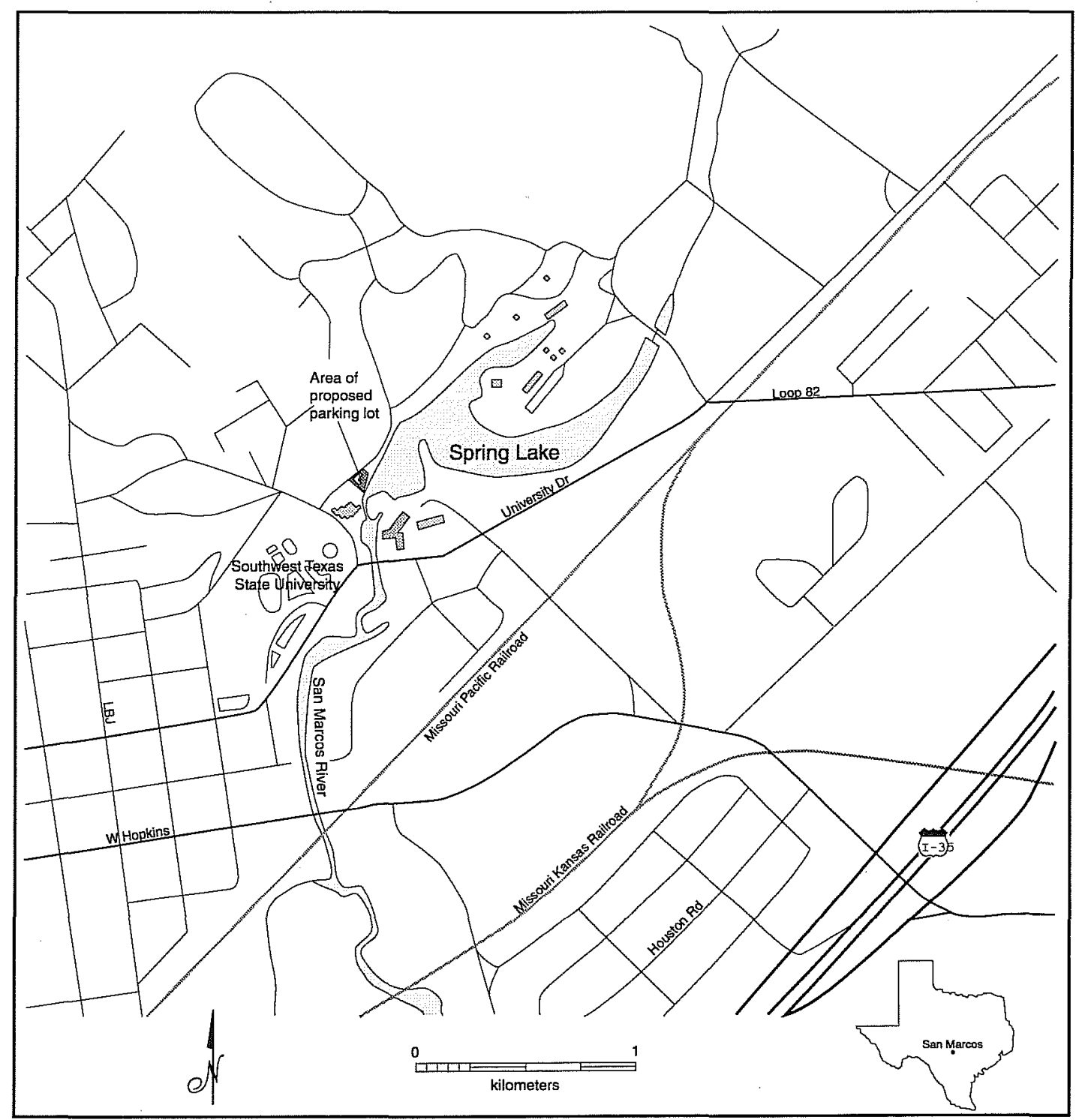

Figure 1. Location of the Spring Lake Project area. 
This page has been

redacted because it

contains restricted

information. 
associated features some 60 years earlier. Due to the high amount of prehistoric cultural material previously identified around Spring Lake, CAR recommended that a pedestrian survey, shovel testing, and backhoe trenching be initiated within the $846-\mathrm{m}^{2}$ lot.

\section{Natural Setting and Environment}

The project area is located on the edge of the Balcones Escarpment. This region has been designated the Balconian biotic province and the Juniper-OakMesquite Savanna vegetation area (Black 1989a: 10-12). It can be defined further as the transition zone between the Edwards Plateau and the Blackland Prairie (Arnn 1997; Ricklis et al. 1991). It is commonly characterized by clay soils generalized as Oakalla silty clay loam. Oakalla is further defined by rarely flooded and frequently flooded types (Batte 1984). Lower soil horizons are characterized by red clay deposits (Shiner 1983).

According to Ogden et al. (1986:116), "the San Marcos Springs are the second largest spring group in Texas with a mean history flow of $161 \mathrm{cfs}\left(4.50 \mathrm{~m}^{3} / \mathrm{sec}\right)$." Spring Lake was created in the third quarter of the nineteenth century by a dam at the headwaters of the San Marcos River (Shiner 1983). Today the lake has

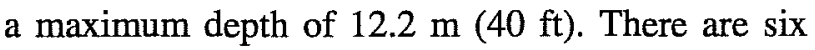
major springs with numerous smaller openings that maintain a constant temperature of $71^{\circ} \mathrm{F}$. The lake is at an elevation of $175 \mathrm{~m}(574 \mathrm{ft})$ above mean sea level (Garber et al. 1983; Ogden et al. 1986). The natural springs, flowing at 150-300 million gallons per day from the Edwards Aquifer, attract and support an abundance of flora and fauna (Shiner 1983).

The modern landscape supports juniper (cedar), mesquite, cottonwood, oak, pecan, and bald cypress (Blair 1950; Ricklis and Collins 1994). Prehistoric species of fauna that no longer inhabit the region included bear, bison, wolf, and antelope (Black 1989a). Blair also lists 49 species of mammals, two land turtles, 16 lizards, 39 snakes, and 23 amphibians for the biotic province. In respect to the immediate Spring Lake Parking Lot project area,
Three federally listed endangered species are present in the San Marcos River and riparian environment. These include the San Marcos salamander (Eurycea nana), the fountain darter (Etheostoma fonticola), and the San Marcos gambusia (Gambusia georgei) [Cargill and Brown 1997:4].

\section{Prehistoric and Historic Background}

Regional and local archaeological investigations relevant to the project area have been initiated over the past two decades. These projects have commonly identified archaeological evidence for human occupation spanning all major culture history periods. The following cultural period temporal designations are derived from Collins (1995).

\section{Paleoindian (ca. 11,500-8800 B.P.)}

In the past it has been generally accepted that the peoples of this time period were nomadic, big-game hunters. However, recent research suggests that a more complex hunting and gathering strategy existed. This strategy can be described as a well-adapted technology to hunt large game, but with plant and other resource gathering and small game hunting aspects existing as well (Collins 1995). Shiner (1983) suggests that these early hunters and gatherers of the Central Texas region heavily utilized fresh water spring environments for subsistence. Sites excavated around Spring Lake that have produced Paleoindian tool types include site 41HY160.

\section{Archaic (ca. 8800-1200/1300 B.P.)}

The Archaic period in Central Texas has been divided into three subperiods: Early Archaic (8800-6000 B.P.), Middle Archaic (6000-4000 B.P.) and Late Archaic (4000-1200 or 1300 B.P.). As in the Paleoindian period, the people of the Archaic continued to utilize and exploit the natural spring environments along the Balcones Escarpment. One logical explanation for continued dependence on these types of constant water sources is the increasingly arid conditions charac- 
teristic of the Archaic (Black 1989b; Cargill and Brown 1997; Collins 1995; McKinney 1981). Lithic tools dating throughout the Archaic periods have been found previously at sites $41 \mathrm{HY} 37,41 \mathrm{HY} 147$, $41 \mathrm{HY} 160$, and 41HY165.

\section{Late Prehistoric (ca. 1200-350 B.P.)}

The springs environment was an important resource area during the Late Prehistoric period as well. Technological markers for the Late Prehistoric include the Perdiz arrow point and the use of pottery (Collins 1995). Artifact assemblages of these types have been identified in Balcones Escarpment springs and surrounding riverine environments including Spring Lake. Sites excavated around Spring Lake that have yielded Late Prehistoric material include 41HY37, $41 \mathrm{HY} 160$, and $41 \mathrm{HY} 165$.

\section{Historic (ca. 260 B.P.-present)}

The Historic period begins with the arrival of Europeans to central Texas. The distinguishing advantage of historic period archaeology is the availability of written records documenting the presence and activities of native and non-native peoples in the region (Collins 1995).

\section{Previous Archaeology}

Archaeology initiated by SWTSU field schools since 1982 have resulted in the excavation of numerous sites located around Spring Lake (Ringstaff, Brown, and Driver, personal communications; Garber et al 1983; Garber and Orloff 1984) including sites 41HY37, $41 \mathrm{HY} 160,41 \mathrm{HY} 161$, and 41HY165. Other work includes underwater investigations by Shiner (1979, 1983). Also, downriver from the Spring Lake, a recent project conducted by CAR resulted in the testing of 41HY261, a stratified, terrestrial site representing ca. 5,000 years of prehistoric activities (Cargill and Brown 1997). Archaeological site types associated with the Balcones Escarpment, including the Spring Lake vicinity, consist of open occupation, burned rock midden, and lithic sites (Black 1989b).

\section{Field Methodology}

Methods of testing for the project included pedestrian survey, backhoe trenches (BHTs), and shovel tests (STs). The residential structure (i.e., the yellow house) had been recently removed from the project area. Subsequently, subsurface testing was initiated to determine the presence of prehistoric and historic cultural remains and any amount of possible contextual disturbance. The pedestrian survey was conducted by three archaeologists walking the entire lot surface in five meter transects. Surface visibility ranged from 25 to 100 percent depending on the presence of low grass. The two BHTs were excavated to depths of 1.2 and $1.8 \mathrm{~m}$. Each backhoe trench excavation was supervised by an archaeologist. Backhoe trenches reflected soil horizon and zone information and were excavated to the water table as requested by the contractor.

Eleven shovel tests were excavated (Figure 3). Six shovel tests (STs 1-6) were established on a grid at approximately $13-\mathrm{m}$ intervals, while STs 7 and 8 were placed between the residence and the lake shore. Three more shovel tests were conducted around ST 2 at fivemeter intervals after laboratory analysis revealed a heavy concentration of lithic material in this region. The three shovel tests (STs 9-11) were initiated to further define the boundaries of the lithic material deposit and amount of contextual disturbance. Each shovel test was excavated in 10-cm levels to a depth of $50 \mathrm{~cm}$ whenever possible.

\section{Results}

\section{Geoarchaeology}

Between the two backhoe trenches excavated, four geological zones were identified. The first and second zones identified were of purely modern origin. Zone 1 was a $10-\mathrm{cm}$ layer of imported topsoil. Zone 2 exists as a light yellow brown caliche gravel mix laid as construction foundation for a residence constructed earlier this century. This foundation layer, where present, was generally about $10 \mathrm{~cm}$ thick. 


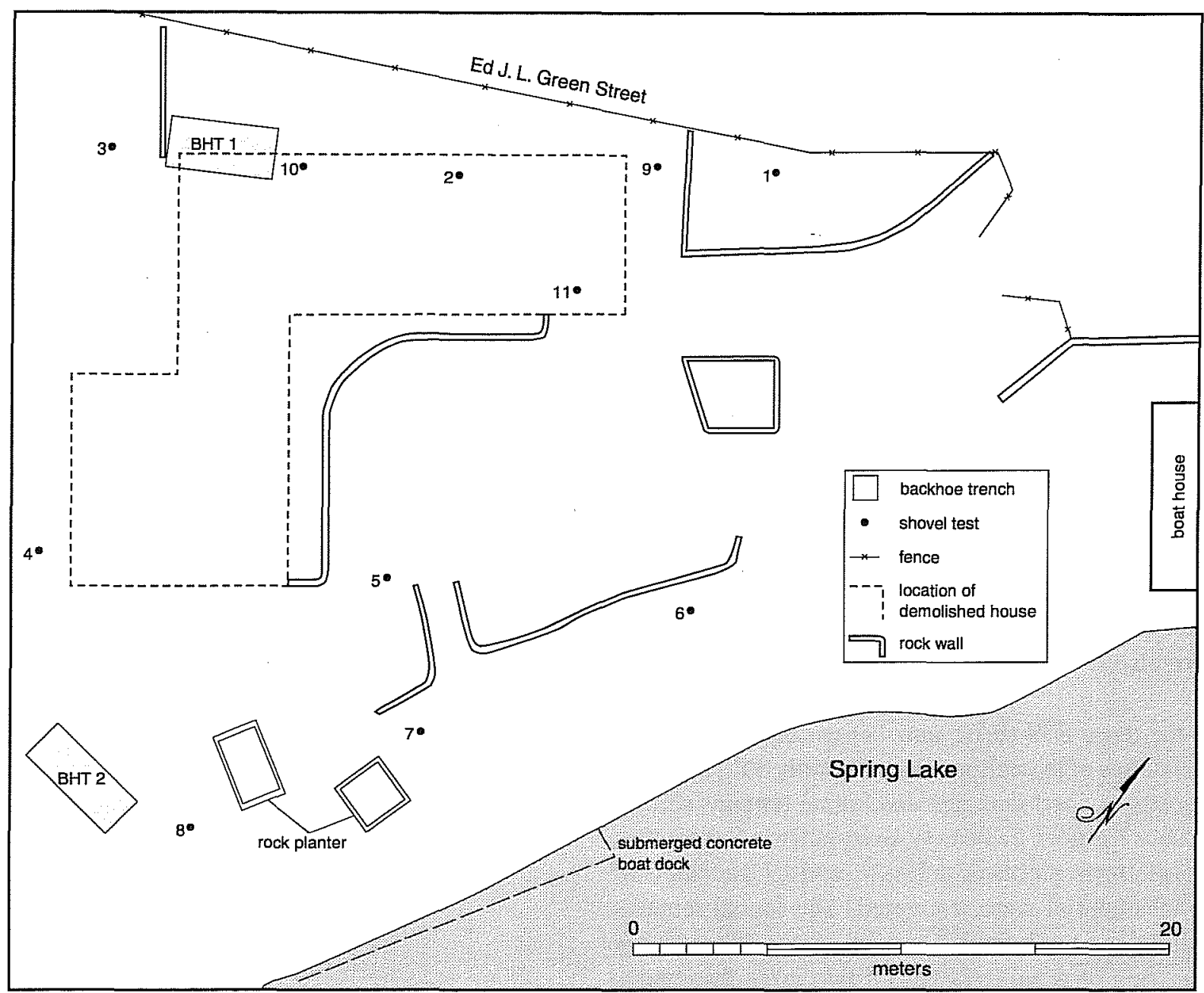

Figure 3. Location of shovel tests and backhoe trenches.

Zone 3 was identified as the native $\mathrm{A}$ horizon. This dark grayish brown clay loam of medium blocky structure contains about five percent gravels. Historic and prehistoric materials coexist in this horizon in a mixed state. This mixed state can be attributed to several causes. Long tree roots are present in the A horizon as is possible disturbance from the construction of the yellow house. Alluvial flooding from the springs and wash from the terraces located behind the lot are also suspected to contribute to the mixed state of cultural remains. Zone 4 is a deep orange red clay loam of fine to medium blocky structure. Calcium carbonate nodules and snails were common, while roots were uncommon.

Shiner (1983) had previously identified a red sand layer between what we identified as Zones 3 and 4 . $\mathrm{CAR}$ archaeologists did not encounter this layer during testing of the lot. Shiner further defines our Zone 3 as containing predominately Archaic and Late Prehistoric materials, while our Zone 4 contained almost solely Paleoindian materials. The red sand layer absent from our project area was described as a mix of Archaic and Paleoindian material. Excavations by SWTSU field schools in 1982 also did not encounter the red sand layer described by Shiner (Garber et al. 1983).

\section{Archaeology}

The majority of the shovel tests encountered evidence of modern construction or ended due to natural disturbances. STs 1, 3, 4, 5, 6, and 7 encountered (respectively): burned construction slag; a cement slab from a buried sidewalk; a sewer line; a rusty utility pipe, which was possibly an abandoned gas line; dense 
construction fill gravels; and a large root from one of the many cottonwood trees located on the property.

Artifacts recovered from the shovel tests were analyzed in the laboratory, and assigned to one of six categories: platform flakes, nonplatform debitage, bone, glass, metal, and other. For a list of material recovered by level for each shovel test, see Appendix A.

Laboratory analysis of recovered remains showed that, while in a disturbed context, a large amount of prehistoric material was recovered from ST 2. Artifacts recovered from ST 2 include five platform flakes, 11 non-platform pieces of chert debitage, and 19 faunal remains. All bone fragments represent small-medium mammals. Three of the bones fragments were burned, one was identified as a small rodent tooth. Six pieces of metal, one of which was a machine-cut square nail, were also recovered from ST 2.

Of the three STs $(9,10$, and 11) excavated to define boundaries of the cultural deposits, only ST 9 included deposits of chert debitage and faunal remains similar to those from ST 2. Twenty-two platform flakes, nine non-platform pieces of debitage, and 19 fragments of faunal material were recovered. The faunal remains include one tooth from Canis sp., from either a very large dog or a wolf (Level 1); two large fragments, probably cow, which exhibit machine saw marks (Levels 2 and 3); and 11 bone fragments representing small-medium mammals and one from a small bird (Level 5). Also recovered from ST 9 were two wire nails from Level 5 and five glass fragments.

The recovery of modern materials (glass, metal nails, buried utility pipe, etc.) confirmed the existence of disturbance to the upper levels of soil on the house lot. The yellow house and its associated features (sidewalks, boatdock, etc.) have been in use in recent years (Figure 3).

\section{Summary and Recommendations}

People have lived near Spring Lake and utilized the resources in and around the springs for at least the past 12,000 years. Today the Spring Lake area contains rich deposits of prehistoric cultural material, as well as recent residences such as the yellow house. Modern and historic construction has disturbed the portion of the lake side represented in the project area. Due to the disturbed nature of this small lot, the planned construction of a parking lot will not critically impact the undisturbed cultural remains that have been previously identified around Spring Lake. On August 28, 1997, Mark Denton of the THC concurred with CAR's recommendation that this project would not adversely impact any cultural remains and permitted clearance for the project. 


\section{References Cited}

Arceneaux, E.

1997 San Marcos River Habitat Conservation Plan: Excerpt for Employee/Overflow Parking Lot for Joe's Crab Shack, San Marcos, Texas. Prepared for Southwest Texas State University.

Arnn, J. W., III

1997 Archaeological Monitoring of a Sidewalk Construction Project in Landa Park, New Braunfels, Comal County, Texas. Archaeological Survey Report, No. 254. Center for Archaeological Research, The University of Texas at San Antonio.

Batte, C. D.

1984 Soil Surveys of Comal and Hays Counties, Texas. Soil Conservation Service, Temple, Texas.

Black, S. L.

1989a Environmental Setting. In From the Gulf Coast to the Rio Grande: Human Adaptation in Central, South, and Lower Pecos Texas, edited by T. R. Hester, S. L. Black, D. G. Steele, B. W. Olive, A.A. Fox, K. J. Reinhard, and L. C. Bement, pp. 5-16. Research Series No. 33 Arkansas Archaeological Survey, Fayetteville.

1989b Central Texas Plateau Prairie. In From the Gulf Coast to the Rio Grande: Human Adaptation in Central, South, and Lower Pecos Texas, edited by T. R. Hester, S. L. Black, D. G. Steele, B. W. Olive, A.A. Fox, K. J. Reinhard, and L. C. Bement, pp. 17-38. Research Series No. 33 Arkansas Archaeological Survey, Fayetteville.

Blair, W. F.

1950 The Biotic Provinces of Texas. The Texas Journal of Science 2(1):93-117.

Cargill, D., and M. Brown

1997 Archaeological Testing at Crook's Park in San Marcos, Hays County, Texas. Archaeological Survey Report, No. 263. Center for Archaeological Research, The University of Texas at San Antonio.

Collins, M. B.

1995 Forty years of Archaeology in Central Texas. Bulletin of Texas Archeological Society 66:361-400.

Garber, J., and M. D. Orloff

1984 Excavations at 41HY37: An Archaic Site on the Balcones Escarpment in San Marcos, Texas. La Tierra 11(3):31-37.

Garber, J. F., S. Bergman, B. Dickinson, R. Hays III, J. Simpson, and J. Stefanoff

1983 Excavations at Aquarena Springs, San Marcos, Texas. La Tierra 10(2):38-38.

McKinney, W. W.

1981 Early Holocene Adaptions in Central and Southwestern Texas: The Problem of the Paleoindian-Early Archaic Transition. Bulletin of the Texas Archeological Society 52:91-120. 
Ogden, A. E., R. A. Quick, and S. R. Rothermel

1986 Hydrochemistry of the Comal, Hueco, and San Marcos Springs, Edwards Aquifer, Texas. In The Balcones Escarpment: Geology, Hydrology, Ecology and Social Development in Central Texas. Geological Society of America Annual Meeting. San Antonio.

Ricklis, R. A., M. D. Blum, and M. B. Collins

1991 Archeological Testing at the Vera Daniel Site (41TV1364), Zilker Park, Austin, Texas. Studies in Archeology 12. Texas Archeological Research Laboratory, The University of Texas at Austin.

Ricklis, R. A., and M. B. Collins

1994 The Environmental Context. In Archaic and Late Prehistoric Human Ecology in the Middle Onion Creek Valley, Hays County, Texas, edited by M. B. Collins and R. A. Ricklis, 1:27-36. Studies in Archeology 19. Texas Archeological Research Laboratory, The University of Texas at Austin.

Shiner, J.

1979 Survey and Testing of the Ice House Site: San Marcos, Hays County, Texas. Southern Methodist University, Dallas.

1983 Large Springs and Early American Indians. Plains Anthropologist 28:1-7. 


\section{Appendix A: Artifact Data}

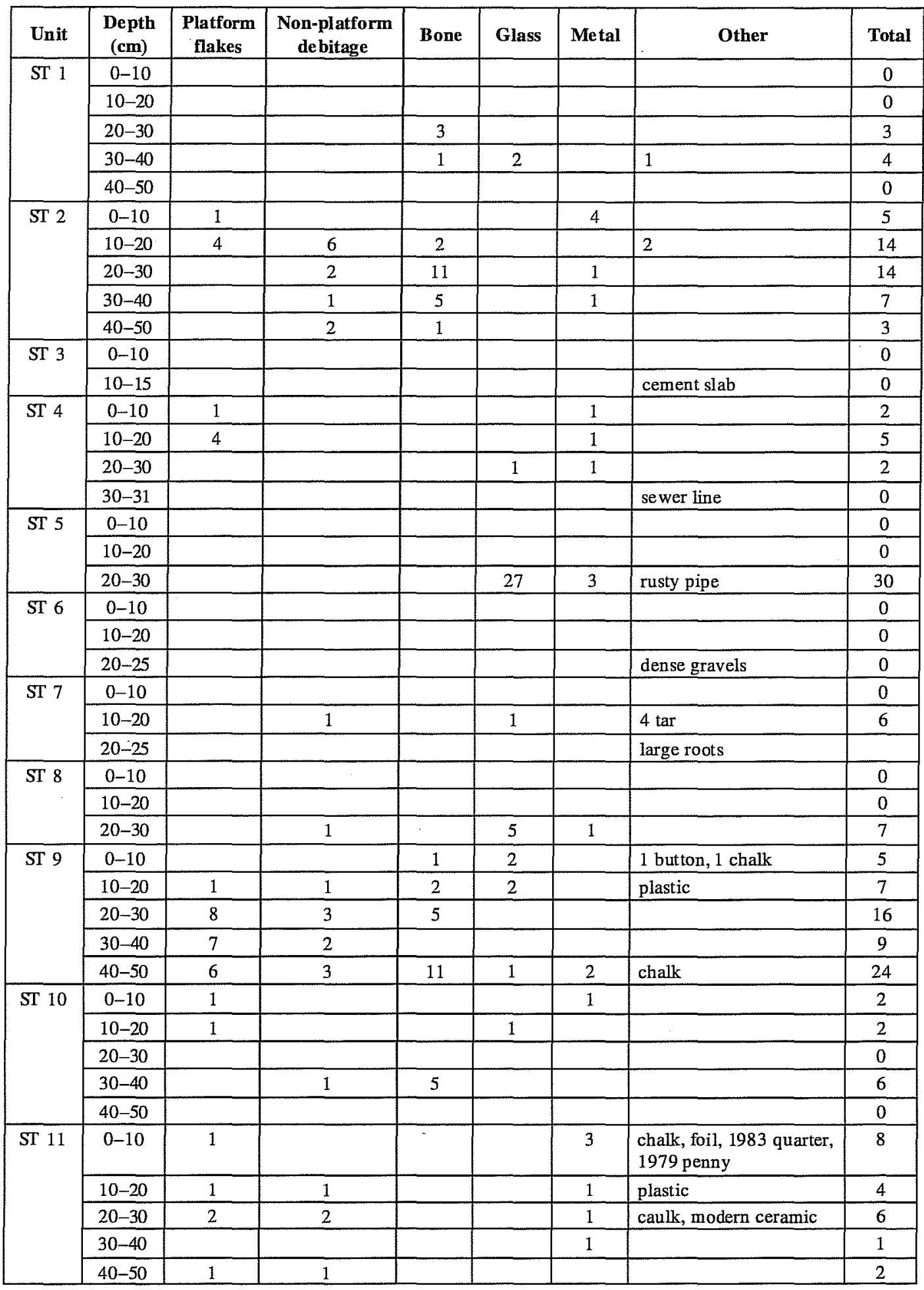


